\title{
NEW METALLOGENETIC CONCEPTS AND SUBSTAINABILITY PERSPECTIVES FO NON-ENERGY METALLIC MINERALS IN CENTRAL MACEDONIA, GREECE
}

\author{
Arvanitidis N. D. ${ }^{1}$ \\ ${ }^{1}$ Institute of Geology and Mineral Exploration (IGME), Fragon 1, 52646 Thessaloniki, \\ narvanitidis@thes.igme.gr
}

\begin{abstract}
Greece's geology favours a potent and dynamic use of mineral resources, which became a major incentive of the country's mining business, and economic and social growth. Among the Non-Energy Metallic Minerals (NEMM) commodities, base and precious metals, in particular copper and gold, is becoming an increasingly important and rapidly growing target of the mining industry. In the region of central Macedonia, where most of their deposits are hosted, the NEMM occur in a wide range of genetic types related to Alpine orogenic and subduction related ore forming processes extending from Mesozoic to Cenozoic times, and culminating during the Tertiary (Arvanitidis and Amov, 2006). From the global metallogenetic point of view the post-Alpine Tertiary geodynamic systems in SE Europe are potential in producing high-grade ore deposits of base and precious metal sulphide minerals. The classification of NEMM mineralizations to specific genetic types, along with the geological knowledge available, is contributing (a) to more efficient exploration and prospect evaluation (b) to safer assessment of ore potential and economic perspectives (c) to rational management of resource production, and (d) in applying sustainable development practices.
\end{abstract}

\section{Introduction}

This paper focuses on the NEMM of central Macedonia in northern Greece (Diakakis and Stephanidis, 1994) using new metallogenetic aspects for implementing low-risk exploration campaigns, reducing environmental footprints and securing sustainable supply and use of commodities (Arvanitidis, 2003).

\section{Regional Geology and Mineralizations}

The sulphide mineral deposits in Greece are mainly located, in the Rhodope and Serbomacedonian zones. The western and central parts of the Rhodope zone consist mainly of Paleozoic high-metamorphic rocks, but its eastern part is dominated by Tertiary volcanics. The Tertiary volcanic belt extends through the northern Mediterranean, Romania, Bulgaria, Greece, Turkey and Iran and is characterized by subduction - related intermediate to felsic volcanics (Jankovic et al., 1980; Heinrich and Neubauer, 2002) (Fig. 1). The belt hosts numerous vein - type (e.g. Kirki, Madjarovo) and stratiform (e.g. Essimi) $\mathrm{Pb}-\mathrm{Zn}$ sulphide mineralisations as well as epithermal gold (e.g. Konos, Perama; Michael et al., 1995; Voudouris et al., 2007) and porphyry copper deposits (Frei, 1995; Tobey et al., 1998). The highly metamorphosed carbonate and silicate rocks to the west, contain vein and massive sulphide replacement mineralisations, ranging from base metal (e.g. Thermes, 


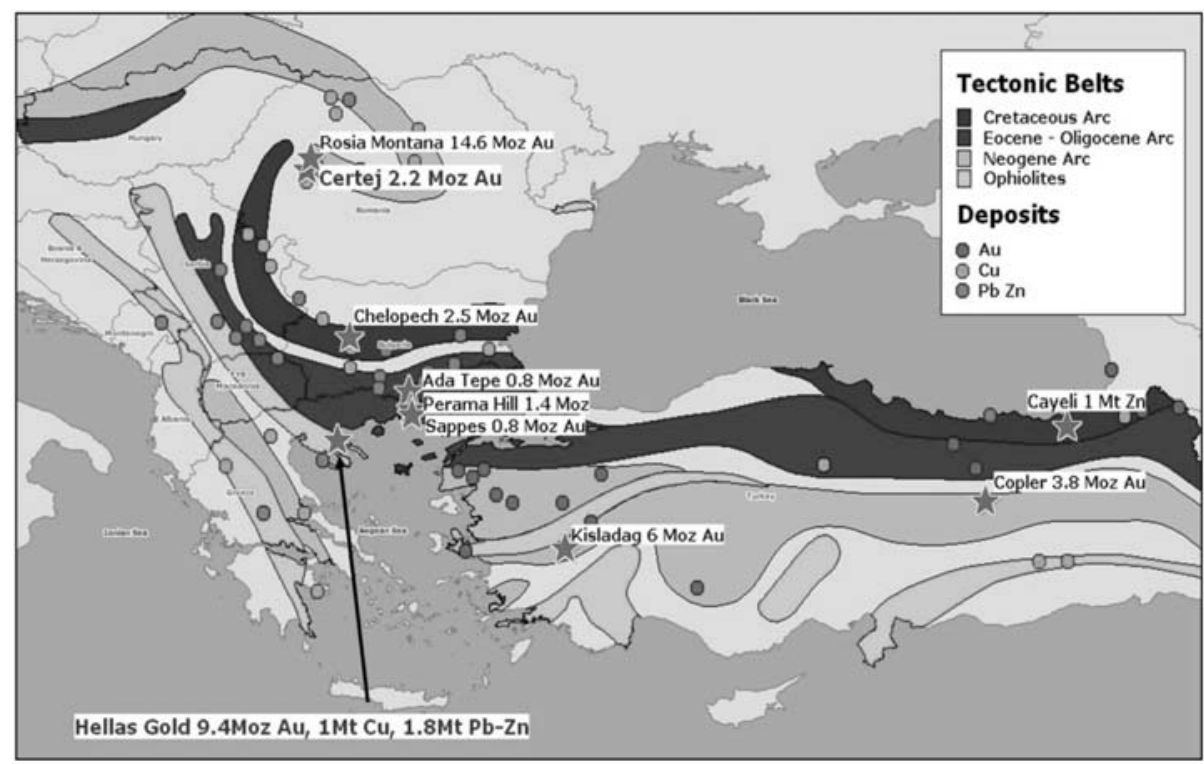

Fig. 1: Regional geotectonic map of southeast Balkan showing the major metallogenetic belts and related mineralization types (European Goldfields Inc, pers. Com.).

Madam) to polymetallic (e.g. Farasino, Pangeo) compositions, and stratabound karst - related $\mathrm{Pb}-$ Zn sulphide (e.g. Thassos) to manganese (e.g. Drama) deposits. The Serbomacedonian zone represents the accretionary back land beneath which the African plate was subducted. The zone is a complex metamorphic terrain of schists, gneisses and marbles that are often mineralized and intruded by Variscan granitic rocks. It trends NW, is some $500 \mathrm{~km}$ long, and is host to numerous deposits, including Olympias and Stratoni polymetallic deposits, and Skouries and Pontokerasia, porphyry copper in Greece, Sasa and Zletovo $\mathrm{Pb}$ - Zn deposits, and Bucim porphyry copper in the Former Yugoslav Republic of Macedonia, as well as the Lece polympetallic deposit in Serbia - Montenegro. In the case of the polymetallic and/or $\mathrm{Pb}-\mathrm{Zn}$ sulphide replacement deposits such as Olympias, Stratoni and Madem Lakkos, they are controlled by a combination of the marble horizons, that contain the carbonates which were replaced and the deep - seated faults developed as part of the crustal re-working of the area and subsequent fluid movements along these. The porphyries are mainly part of the Variscan volcanism. The Skouries deposit is a typical representative of sub-alkaline copper porphyry forming a near-vertical pipe intruded into amphibolite and biotite schist country rock.

\section{Genetic Types}

NEMM mineralization in the region of central Macedonia comprises (Fig. 2).

Mesozoic mid-ocean types in terms of,

- Magmatic/ophiolites hosted chromite, Fe-Ni laterites and chalcopyrite-pyrite-pyrrhotite assemblages

- Volcano-sedimentary syngenetic deposits including VMS type stratiform base metal sulphides, stratified chalcopyrite-pyrite-arsenopyrite lenses, banded iron formations and scheelite $(\mathrm{W})$ veins/disseminations

- Intrusion related porphyry type Mo stockwork veins and impregnations, and 


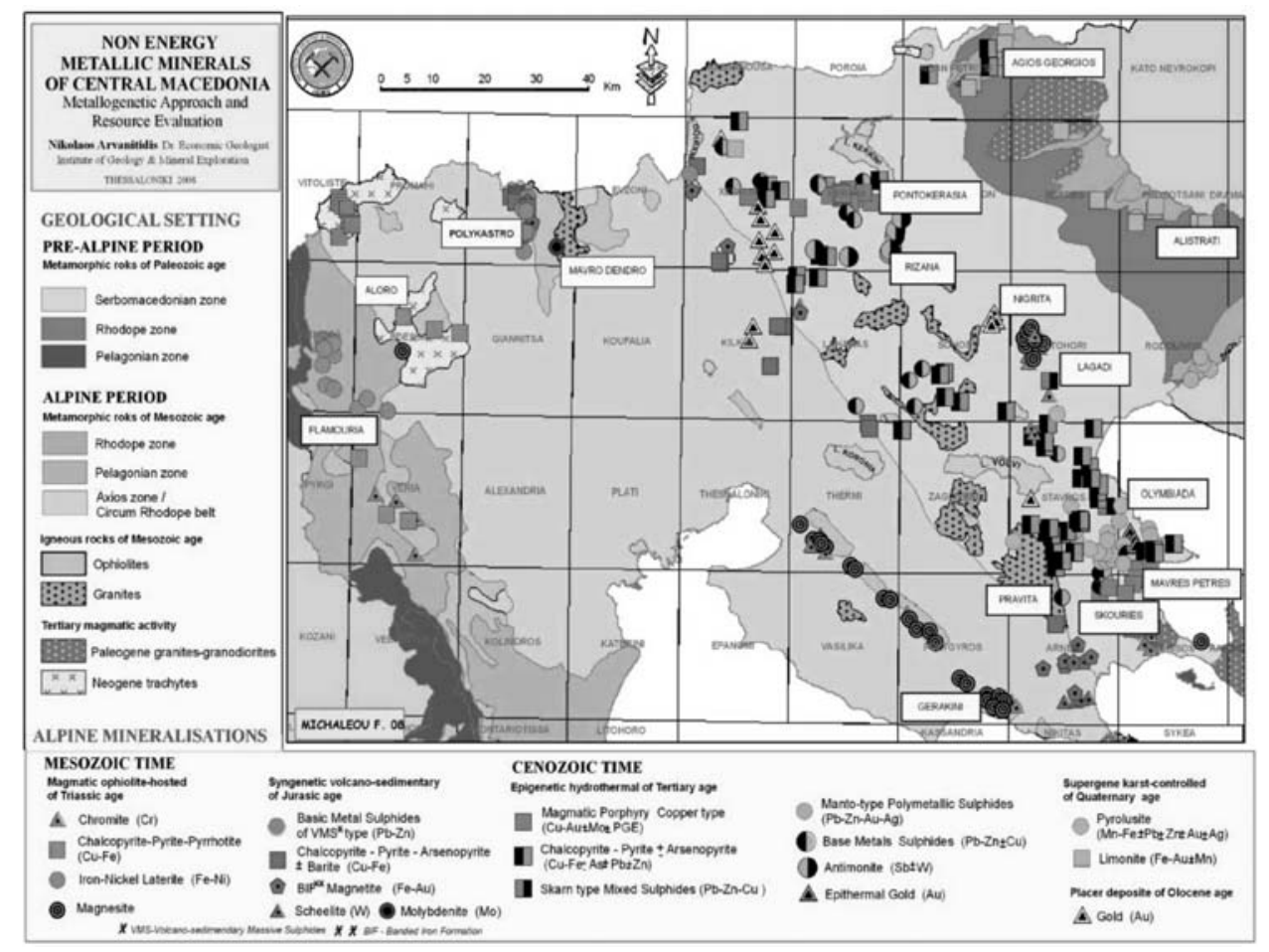

Fig. 2: Simplified geological map showing the main Alpine orogenesis related polymetallic mineralizations in the region of central Macedonia.

Cenozoic, mainly Tertiary, epigenetic, hydrothermal types of,

- Magmatic porphyry Cu-Au deposits containing elevated values of PGE and associated with calc-alkaline sub-volcanic intrusions (Eliopoulos and Economou-Eliopoulos, 1991)

- Hypothermal/Mesothermal chalcopyrite-pyrite-arsenopyrite veins hosted by amphibolites

- Skarn formations of $\mathrm{Cu}-\mathrm{Zn}-\mathrm{Pb}$ sulphides

- Manto type polymetallic ( $\mathrm{Pb}-\mathrm{Zn}-\mathrm{Au}-\mathrm{Ag})$ massive sulphides

- Antimonite (Sb) - scheelite (W) veins (Kilias et al., 1995)

- Epithermal gold $(\mathrm{Au})$ along with fault-controlled silicification and pyritization zones

- Supergene fault/karst-controlled mineralization of economic pyrolusitic manganese and gold bearing limonitic iron oxidations

- Placer gold deposits

\section{Gold Mineralizations}

Gold occurs in a wide range of genetic types, comprising magmatic, hypothermal / mesothermal, epithermal and supergene mineralization types (Arvanitidis, 2003; Melfos et al., 2003). All the main types of gold mineralization are linked to plate tectonic movements during the Tertiary.

Magmatic porphyry copper type deposits and mineralizations show economic gold grades. The Skouries gold-copper ore deposit (Frei, 1995; Tobey et al., 1998) is located 20km southwest of the 

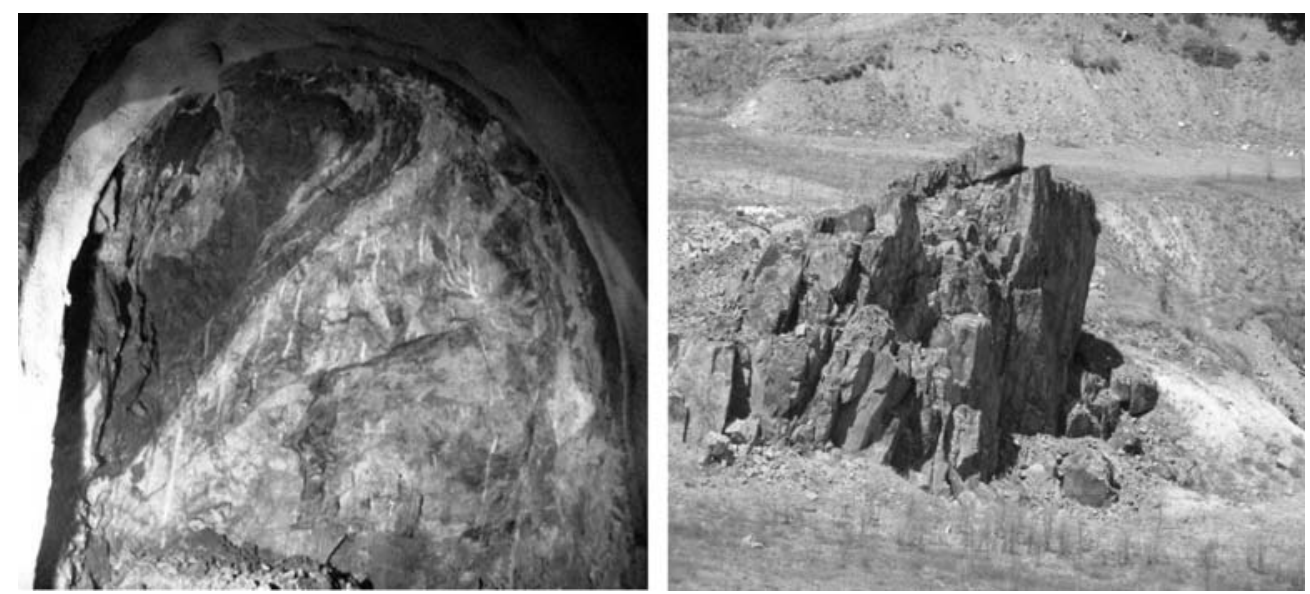

Fig. 3: Typical ore structures of manto-type stratabound sphalerite lens (left) in Mavres Petres mine and malachite impregnations in Skouries porphyry copper mineralization.

Olympias mine and the most representative example of this class (Fig. 3). It is a typical sub - alkaline copper porphyry forming a near - vertical pipe intruded into amphibolite and biotite schist country rock. The deposit is characterized by concentric alteration zones comprising an inner potassic zone, with stock work quartz veinlets and an outer propylitic zone, affecting mostly the host schists. Weak phyllic and argillic alteration is confined to vein haloes and faults. Mineralisations within the potassic zone primarily comprise chalcopyrite veinlets with subordinate bornite and disseminated chalcopyrite and bornite. Mineralisation within the propylitic zone contains disseminated pyrite, molybdenite and rare chalcocite. Gold mineralisation occurs as native gold associated with gangue minerals. It also occurs as blebs within sulphides and occurs in the ore during testing. An oxide zone occurs from surface to 30 to 50 meter depths and includes malachite, cuprite, secondary chalcocite and minor azurite, covellite, digenite and native copper. The total resources were estimated to $191,200,000$ tonnes, with $0.82 \mathrm{~g} / \mathrm{t}$ gold and $0.55 \mathrm{wt} \%$ copper, or in terms of total metal amounts, 5.03 Moz gold and 1.043.000 tonnes copper. Current reserves are estimated to 129,500,000 tonnes, with $0.89 \mathrm{~g} / \mathrm{t}$ gold and $0.56 \mathrm{wt} \%$ copper, corresponding to metal amounts of $3.71 \mathrm{Moz}$ gold and 725,000 tonnes copper (Hellas Gold, pers. com.).

Hypothermal / mesothermal manto-type polymetallic sulphides form high - grade gold ores (Kalogeropoulos et. al., 1989; Hellingwerf et. al., 1993; Kalogeropoulos et. al., 1996; Kilias et. al., 1996). The Olympias massive deposit, representing this class, is a stratabound replacement orebody occurring at the contact between marbles and overlying gneisses. Sulphide mineralisations comprises pyrite, arsenopyrite, sphalerite, galena, tetrahedrite - tenantite, boulangerite and chalcopyrite. Gold values are associated almost exclusively with arsenopyrite and pyrite. The total resources and nearly reserves, were estimated to $14,528,000$ tonnes, with $9.31 \mathrm{~g} / \mathrm{t}$ gold, $128.6 \mathrm{~g} / \mathrm{t}$ silver, 4.18 wt\% lead and $5.58 \mathrm{wt} \%$ zinc (Hellas Gold S.A., pers. com). Corresponding total amounts of metal contents are 4.35 Moz gold, 60.06 Moz silver, 607,000 tonnes $\mathrm{Pb}$ and 810,000 tonnes zinc. Further to the north, the Stratoni lead-zinc-silver deposits are also considered as carbonate replacement type mineralisations, with pyrite, galena, sphalerite, arsenopyrite and chalcopyrite as the main sulphide minerals. The entire resources are currently located in the Mavres Petres mine contained within a marble-hosted stratabound orebody adjacent to the east-west striking Stratoni Fault. The ore is also gold bearing, mostly associated with the arsenical pyrite and arsenopyrite. Quartz, calcite and minor 
rhodochrosite form the gangue minerals. The total sulphide content prior to mining was estimated at 2.5 Mt (Hellas Gold, pers. com.).

Epithermal type deposits were emplaced within a broad volcanic belt, which developed first in Bulgaria and then moved south through northern Greece (Marchev et al., 2005) to the region of Thrace. The Konos - Sappes and Perama high sulphidation gold mineralizations (Michael et al., 1995; Voudouris et al., 2007; Michael, 2004), in strongly silicified and/or argillised felsic volcanics, make a typical representative of this class. A rhenium-rich molybdenite and rheniite $\mathrm{Mo}-\mathrm{Cu}-\mathrm{Te}-\mathrm{Ag}-$ Au porphyry mineralization located in the Pagoni Rachi area shows close geotectonic setting affinities to the epithermal metallogenesis of the region (Voudouris et al., 2009).

The genetic link between porphyry coppers and large polymetallic manto style sulphide deposits can be incorporated into regional exploration strategies. The metallogenetic concept suggests that epithermal mineral assemblages exposed at the present land surface may indicate hidden base metal ore bodies at depth. These styles of mineralization, porphyry coppers and manto - style sulphides, have potential for substantial deposits (Hellingwerf et al., 1994). Gossans in the region have low economic potential due to erratic gold values and the necessity for costly beneficiation techniques (Dimitroula et al., 1995; Arvanitidis et al., 1996). The gossans develop on mineralized veins and thrusts, but the gossanous material tends to spread laterally, giving a false impression of the underlying mineralization. Parts of the gossans can be richer in gold, but these patches mainly constitute small scale exploration targets in west Rhodope.

\section{Metallogenetic approach}

The tectonic structure of Greece consists of elongated tecto-magmatic strips, representing successive subductions, such as the Serbo-Macedonian massif hosting the manto-type massive sulphide Olympias and Stratoni (Madem Lakkos and Mavres Petres orebodies) deposits, and the porphyry copper systems of Skouries, Fisoka, Vathi, Gerakario and Pontokerasia. The overall metallogenetic process of the area is part of the Alpine orogenesis, lasting from Mesozoic to Tertiary times, and associated geodynamic release of anomalous thermal and mechanical energy. The overwhelming evolution of the Tethyan Ocean, during Triassic to Jurassic times, was accompanied by extensive mid-ocean magmatic activity and new oceanic crust formation, including ophiolitic rocks and related mineralizations (Fig. 4). At a very early transitional stage of subducting oceanic crust movements and distal to mid-ocean ridge settings there were conditions of, probably back-arc, calc-alkaline volcano-sedimentary activity along with formation and deposition of syngenetic metallic minerals of VMS (due to later hydrothermal remobilization may sometimes be considered as "hybrid epithermal VMS") and BIF types. The progressively collisional subduction and destruction of Tethys led to compressional tensions and mineralized ophiolitic slabs were thrusted over onto Paleozoic continental margin of Serbo-Macedonian basement rocks. The imposed orogenic mechanism and the associated probably post-subduction extensional tectonics (Richards, 2003 and 2009; Marchev et al., 2005) inferred generated intra-continental syn-orogenic faults, formed rift-basins and activated extensive Tertiary magmatic belts of orogenic I-type plutonic and sub-volcanic rocks which during Miocene differentiated partly to back-arc volcanism (e.g. Aridea volcanic belt). The emerging metallogenetic activity of intensive hydrothermal solutions leads to ore formation of manto-type polymetallic sulphides, coppergold porphyry systems, ISCG-type (Iron Sulphide Copper Gold) gold-bearing pyrite-chalcopyrite -arsenopyrite mineralizations and high sulphidation epithermal gold and $\mathrm{Mo}-\mathrm{Cu}-\mathrm{Te}-\mathrm{Ag}-\mathrm{Au}$ porphyries along with probably post-subduction extension and rift-basin volcanism further to the east in the region of Thrace (Voudouris et al., 2009). This metallogenetic framework has similar geochemi- 


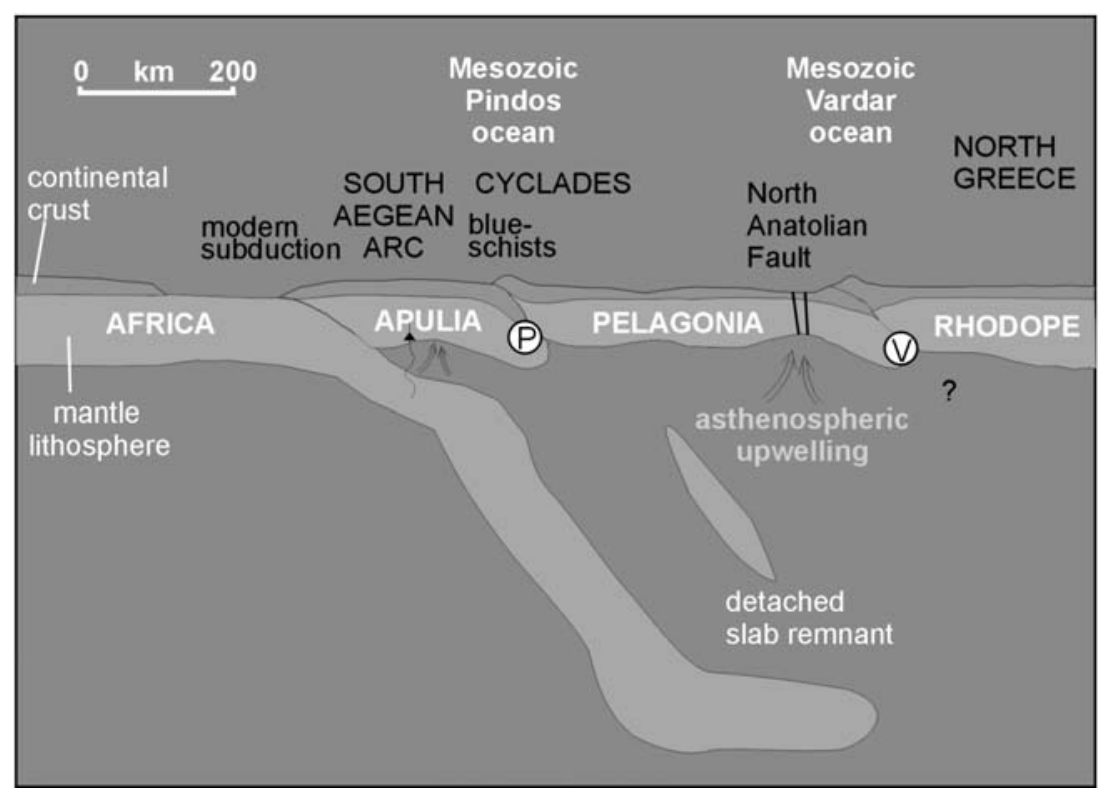

Fig. 4: The main mineralization types in northern Greece and southeast Balkan, and their genetic links to Tethys mid-ocean magmatic activity during Mesozoic and to subduction related orogenic belts during Tertiary (modified after, Pe-Piper, G. and Piper, D.J.W., 2001).

cal affinities with the copper-gold porphyries and the orogenic IOCG (Iron Oxide Copper Gold) type NEMM which at Archean-Proterozoic times are referred to as hybrid porphyry-IOCG style deposits (Weihed et al., 2008). Other typical and common features of the orogenic mineralizations, as the case is for the Tertiary Hellenic mineralizations, are their syn-tectonic and mesothermal characteristics. All previous types of sulphide minerals (particularly those hosted by Rhodope and Serbo-Macedonian marbles) were overimposed by post-Pliocene co-active supergene oxidation and karstification processes (Fig. 5). In spite of the manganese ore formation and the obvious iron enrichment of some occurrences, the metallic content and inter-related commodity grades of the primary sulphide deposits were not particularly affected during supergene oxidation.

\section{Implication of new exploration concepts}

The metallogenetic regime of orogenic and back-arc magmatic belts is globally one of the most dynamic geotectonic environments for the formation of potential polymetallic, porphyry and epithermal type gold deposits. It has been indicated that almost $50 \%$ of porphyry and epithermal type gold occurs in orogenic belts. In this respect, the Alpine or Tethyan orogenic setting makes a high priority target for exploration of Cenozoic NEMM resources and gold deposits in particular. This requires of course further and more systematic ore prospecting of selected regions and areas in Greece and the Balkan Peninsula using new technologies and methods. Based on the geodynamic, spatial and time compliant features of the mineralization types described above, to target and achieve NEMM resource sustainability the following conceptual tools could be applied:

- The local and regional aspects of the metallogenetic evolution which extend the geographical and geological potential of the NEMM resources with respect to transnational targets as for example is the Carpatho-Balkan belt (Jankovic et al., 1980; Heinrich and Neubauer, 2002). 

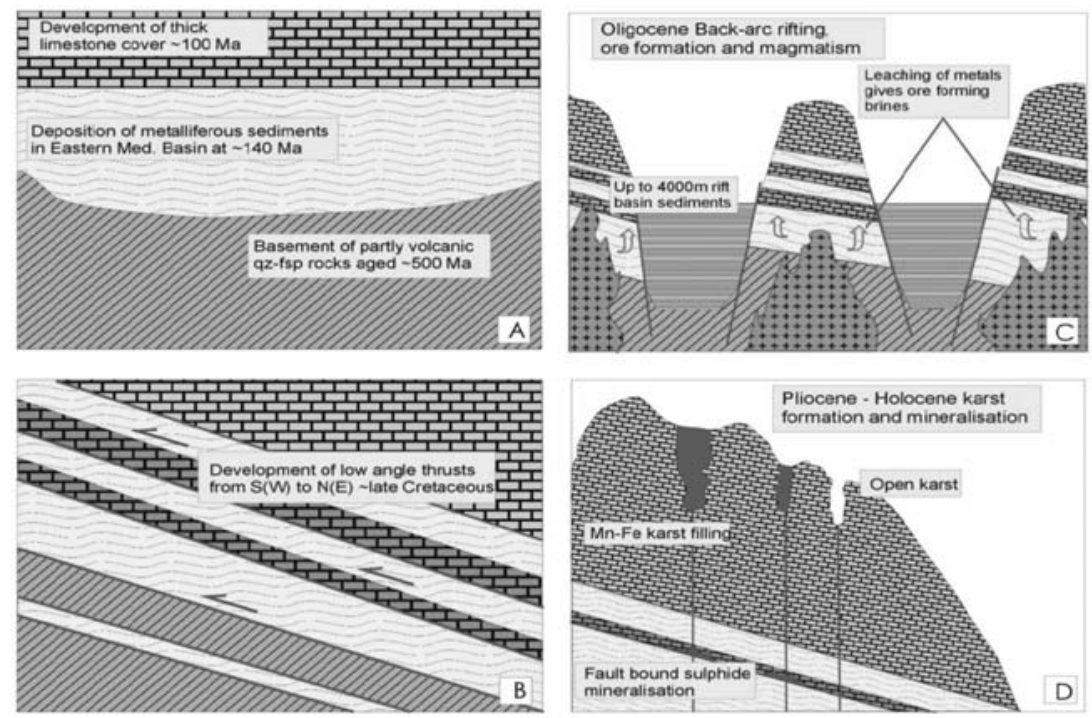

Fig. 5: Schematic integrated four phase mineralization and karst-forming model.

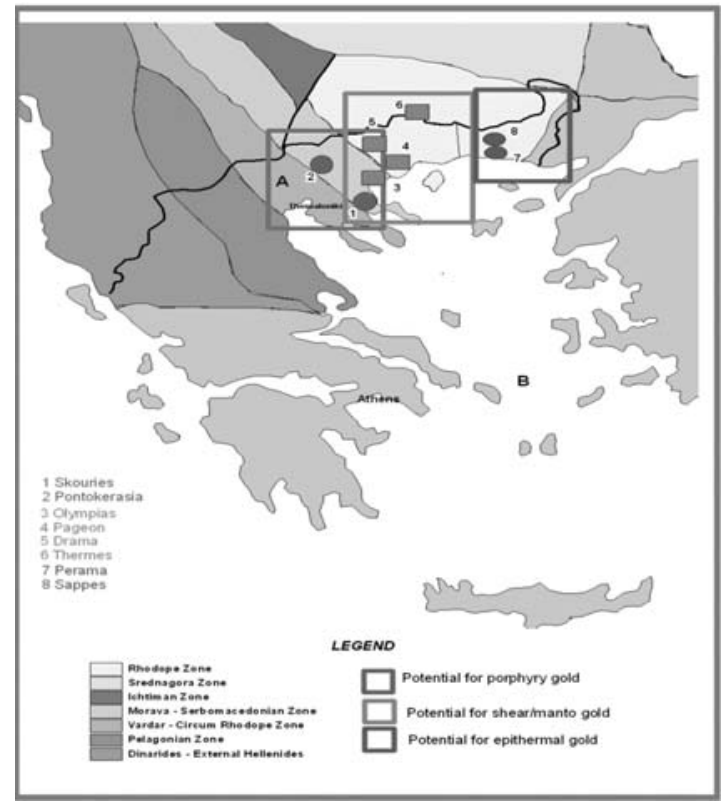

Fig. 6: Major gold potential exploration areas in Greece related to porphyry, mantotype and epithermal mineralization regimes and following the geotectonic and metallogenetic evolution during Cenozoic time.

- The development and implementation of 3D/4D exploration models to locate deep seated mineral deposits in the known manto and porphyry type belts of Serbo-Macedonian zone and the IOCG like supergene assemblages of western Rhodope zone.

- The feasibility studies for the technoeconomical favourable presence of eco-efficient NEMM in the mentioned mineralization types, like for example the promising grades of PGE in the porphyry copper systems, which appear to become critical minerals and hot commodities for the European mining industry. 


\section{References}

Arvanitidis, N. D., Constantinides, D. C., Ashworth, K. L., Baker, J. H., Hellingwerf, R. H., and Epitropou N., 1995. Regional and local metallogenetic concepts in the SerboMacedonian and Rhodope Massifs, Northern Greece, Proceedings of the third Biennial SGA meeting, Praque, Pasava, Kribek and Zak (eds), Balkema, Rotterdam, 27-30.

Arvanitidis, N.D., Tsamantouridis, P., and Dimou, E., 1996. Gold-bearing sulphide and gossans mineralization systems of the Myriophyto Region, central Macedonia, Greece, Geologica Balcanica, 26, 25 36.

Arvanitidis, N., 2003. Gold deposits in Greece genetic types and economic perspectives, Proceed. of the $7^{\text {th }}$ Biennial SGA Meeting on "Mineral Exploration and Sustainable Development" Athens, Millpress Roterdan, 941-943.

Arvanitidis, N. D., and Amov, B., 2006. New geological and metallogenetic interpretation of lead isotopes from mineralizations in Greece, Proceedings of XV III th Congress of the Carpathian-Balkan Geological Association, Serbian Geological Society, Belgrade, 9-12.

Diakakis, M., and Stefanidis, P., 1994. Mineral raw material atlas of central Macedonia, Greece, IGME internal report, Thessaloniki.

Dimitroula M., Chatzipanagis I., Arvanitidis, N. D., and Economou, G. 1995. Gold mineralogy and geochemistry of the iron - manganese gossans in Thymaria area (Palea Kavala), Northern Greece, $X V$ Congress of the Carpatho - Balkan Geol. Ass., Athens, Spec. Publ. of the Geol - Soc of Greece, No 4/2, 704-709.

Eliopoulos, D.G., and Economou-Eliopoulos, M., 1991. Platinum-group element and gold contents in the Skouries porphyry copper deposit, Chalkidiki Peninsula, northern Greece, Economic Geology 86, 740-749.

Frei, R., 1995, Evolution of mineralizing fluid in the porphyry copper system of the Skouries deposit, northeast Chalkidiki (Greece): evidence from combined $\mathrm{Pb}-\mathrm{Sr}$ and stable isotope data; Economic Geology, 90, p. 746-762.

Heinrich, C. H., and Neubauer, Z. F., 2002. $\mathrm{Cu}-\mathrm{Au}-\mathrm{Pb}-\mathrm{Zn}-\mathrm{Ag}$ metallogeny of the Alpine - Balkan - Carpathian - Dinaride geodynamic province, Mineralium Deposita, 37, 533-540.

Hellinqwerf, R. H., Arvanitidis, N. D, and Constantinides D. C., 1993. The Olympias and Madem Lakkos massive sulphide deposits (Chalkidiki Peninsula/Greece): A new metallogenic approach, Abstracts of the Conference on Plate Tectonic Aspects of Alpine Metallogeny in the Carpatho - Balkan Region, Budapest Proceedings, 20- 21.

Hellinqwerf, R. H., Arvanitidis, N. D., and Constantinides D. C., 1994. Ores, exploration tools and new targets in the eastern Chalkidiki peninsula, northern Greece, Bulletin of the Geological Society of Greece vol. XXX/1, 457-467.

Jankovic, S., Petkovic, M., Tomson, I. N. and Kravcov, V., 1980, Porphyry copper deposits in the SerboMacedonian Province, southeastern Europe; in Jankovic, S. and Sillitoe, R.H., eds., European Copper Deposits, Proceedings of International Symposium, Bor, Yugoslavia, September 1979, Society for Geology Applied to Mineral Deposits (SGA), Special Publication 1, 96-101.

Kalogeropoulos, S.I., Kilias, S.P. Arvanitidis, N.D., 1996. Physicochemical conditions of deposition and origin of the carbonate-hosted base metal sulfide mineralization of the Thermes ore-field, Rhodope Massif, NE Greece. Mineralium Deposita, v. 31, p. 407-418.

Kalogeropoulos, S.I., Kilias, S.P., Bitzios, D., Nicolaou, M., Both R.A., 1989. Genesis of the Olympias carbonate-hosted $\mathrm{Pb}-\mathrm{Zn}(\mathrm{Au}, \mathrm{Ag})$ sulphide ore deposit, Eastern Chalkidiki Peninsula, N. Greece. Economic Geology, v. 84, p. 1210-1234.

Kilias S.P., Veranis N., Konnerup-Madsen J., 1995. The nature of the fluids associated with scheelite 
(+gold) mineralization, Metaggitsi-Pravita area, Central Chalkidiki Peninsula, N. Greece. In: Pasava, J., Kribek, B., Zak, and K. (eds.) Mineral Deposits: From their origin to their environmental impacts. Balkema/Rotterdam/Brookfield, pp. 877-880.

Kilias, S.P., Kalogeropoulos, S.I., Konnerup-Madsen, J.,1996. Fluid inclusion evidence for the physicochemical conditions of sulphide deposition in the Olympias carbonate-hosted $\mathrm{Pb}-\mathrm{Zn}(\mathrm{Au}, \mathrm{Ag}) \mathrm{Sul}-$ phide ore deposit, E. Chalkidiki peninsula, N. Greece. Mineralium Deposita, v. 31, p. 394-406.

Marchev, P., Kaiser-Rohrmeier, M., Heinrich, C., Ovtcharova, M., von Quadt, A., and, Raicheva, R., 2005. Hydrothermal ore deposits related to post-orogenic extensional magmatism and core complex formation: The Rhodope Massif of Bulgaria and Greece, Ore Geology Reviews 27, 53-89.

Melfos, V., Vavelidis, M., Bogdanov, K., 2003. Occurrence, mineralogy and chemical composition of primary gold from Tertiary ore mineralization in the Rhodope Massif (Greece-Bulgaria). In: Eliopoulos, D., et al., (Eds.), Mineral Exploration and Sustainable Development. Millpress, Rotterdam, pp. 1201- 1204.

Michael, C., Perdikatsis, V, Dimou, E., Marantos, I., 1995. Hydrothermal alteration and ore deposition in epithermal precious metal deposits of Agios Demetrios, Konos area, northern Greece. Proceedings XV Congress of the Carpathian-Balkan Geological Association, Geological Society of Greece Special Publications no. 4, pp. 778-782.

Michael, C., 2004. Epithermal systems and gold mineralization in western Thrace (north Greece). Bulletin of the Geological Society of Greece vol. XXXVI, pp.416-423.

Pe-Piper, G. and Piper, D.J.W., 2001: Late Cenozoic, post collisional Aegean igneous rocks: Nd, Pb and $\mathrm{Sr}$ isotopic constraints on petrogenetic and tectonic models. Geological Magazine, 138, 653-668.

Richards, J.P. 2003, Tectonomagmatic precursors for porphyry $\mathrm{Cu}$-(Mo-Au) deposit formation: Economic Geology and the Bulletin of the Society of Economic Geologists, v. 96, p. 1515- 1533.; Richards, J.P. 2009 Post-subduction porphyry $\mathrm{Cu}-\mathrm{Au}$ and epithermal $\mathrm{Au}$ deposits: Products of remelting of subduction-modified lithosphere; Geology; March 2009; v. 37; no. 3; p. 247-250).

Tobey, E., Schneider, A., Alegria, A., Olcay, L., Perantonis, G. and Quiroga, J., 1998, Skouries porphyry copper-gold deposit Chalkidiki, Greece: setting, mineralization and resources; in Porter, T. M., ed., Porphyry and Hydrothermal Copper and Gold Deposits: a global perspective, PACRIM ' 98 Conference Proceedings, Australian Mineral Foundation, p. 159-168.

Voudouris, P., Papavasiliou, C., Alfieris, D., and Falalakis, G., 2007. Gold-silver tellurides and bismuth sulfosalts in the high-intermediate sulfidation Perama Hill deposit, western Tharce (NE Greece), $G e$ ological Survey of Finland, Guide 53.

Voudouris et al, 2009. Rhenium-rich molybdenite and rheniite in the Pagoni Rachi Mo-Cu-Te-Ag-Au prospect, northern Greece: implications for the re geochemistry of porphyry-style cu-mo and mo mineralization ;The Canadian Mineralogist Vol. 47, pp. 1013-1036 , 2009.

Weihed, P., Eilu, P., Larsen, R.B., Stendal, H., and Tontti, M., 2008. Metallic mineral deposits in the Nordic countries, Episodes, Vol. 31, No. 1, 125-132. 